\title{
KEBAHAGIAAN PERSONAL DAN DUKUNGAN SOSIAL PADA LANSIA: STUDI PADA LANSIA DI KOMUNITAS KELUARGA DAN PANTI JOMPO
}

\author{
Sofa Amalia'), Miftakhul Ulfa' ${ }^{2)}$, dan Frengki Aprianto ${ }^{3)}$ \\ 1) Mahasiswa Program Magister Psikologi,Universitas Padjadjaran Bandung \\ 1,2,3) Prodi Keperawatan STIKES Widyagama Husada
}

\begin{abstract}
In general, social support of the environment can increase the level of happiness of the elderly. If the level of personal happiness increases, the elderly's life expectancy will increase as well. This study aimed at determining the differences of social support and the level of personal happiness in the elderly in the family and elderly nursing homes. This research used two different samples: the elderly who lived with their family and the elderly in the elderly nursing homes. These two samples were used because the psychological problems that occur on the elderly who lived with their family and who were in the elderly nursing homes were assumed to be different.The samples used were the elderly aging 55 years and above in Malang City. There were 50 people in the group of elderly who lived with their family and 50 elderly who lived in the Pangesti Lawang Nursing Home. The results from different tests showed no difference in personal happiness $(F=0373, p>0.05)$ and social support $(F=$ 0695, $p>0.05)$ in the elderly in the family and community nursing homes, while the correlation test results showed a strong correlation and significant between personal happiness and social support in the elderly $(r=0686, p=0.000)$.

Keyword: Social Support; Personal Happiness, Elderly, Family, Community, Nursing Home
\end{abstract}




\begin{abstract}
Abstrak
Secara harfiah dukungan sosial dari lingkungan dapat meningkatkan tingkat kebahagiaan pada lansia, dengan meningkatnya tingkat kebahagiaan personal angka harapan hidup lansia juga meningkat. Penelitian ini bertujuan untuk mengetahui perbedaan dukungan sosial (social support) dan tingkat kebahagiaan personal (personal happiness) pada lansia di komunitas keluarga dan lansia di panti jompo. Menggunakan dua sampel yang berbeda yakni: lansia di komunitas keluarga dan lansia di panti jompo dengan alasan permasalahan psikologis yang terjadi pada lansia di komunitas keluarga dan panti jompo diasumsikan berbeda. Sampel yang digunakan adalah Lansia usia 55 tahun keatas di Malang Raya, berjumlah 50 Lansia yang tinggal di komunitas keluarga di Malang Raya dan 50 lansia yang tinggal di panti jompo yakni Panti Werdha Pangesti Lawang. Hasil dari uji beda menunjukkan tidak ada perbedaan pada kebahagiaan personal $(\mathrm{F}=0.373, p>0.05)$ dan dukungan sosial $(\mathrm{F}=0.695, p>0.05)$ pada lansia di komunitas keluarga dan panti jompo, sedangkan hasil uji korelasi menunjukkan ada hubungan yang kuat dan signifikan antara kebahagiaan personal dan dukungan sosial pada lansia $(\mathrm{r}=0.686, p=0.000)$.
\end{abstract}

Kata Kunci : Dukungan Sosial ; Kebahagiaan Personal ; Lansia ; Komunitas; Keluarga; Panti Jompo

\section{PENDAHULUAN}

Lansia merupakan tahapan perkembangan manusia usia 60 tahun keatas, dimana pada tahap tersebut manusia telah mengalami penurunan fungsi-fungsi fisik maupun psikologis. Dalam kehidupan seseorang pastilah ingin meraih kebahagiaan, dimana kebahagiaan individu khususnya pada masa lansia dapat tercapai oleh keadaan kesehatan yang baik, dukungan sosial dari lingkungan, aktivitas rutin yang dilakukan, faktor spiritualitas, dll. Tiap-tiap orang memiliki intensitas kebahagiaan yang berbeda-beda pula.

Menurut Bradburn dkk (Ryff, 1989) kebahagiaan (Happiness) merupakan hasil dari kesejateraan psikologis dan merupakan tujuan tertinggi yang ingin dicapai oleh setiap manusia. Aristoteles menjelaskannya dengan sebutan eudomonia (Ryff, 1989). Kesejahteraan psikologis pada lansia penting untuk dikembangkan karena dengan kesejahteraan psikologis lansia menjadi lebih bahagia dan merasakan kepuasaan dalam hidupnya, sehingga menghindarkan mereka dari kesendirian, ketidakbahagiaan, dan depresi. Succesful Aging merupakan langkah penting yang harus dicapai sebagai lansia, dengan tercapainya successful aging akan memiliki tingkat harapan hidup yang lebih tinggi dan akan memiliki tingkat kebahagiaan yang tinggi sebagai akibat dari kepuasaan hidup yang mereka miliki. Namun tidak semua lansia dapat mencapai successful aging. Ketidakberhasilan lansia dalam mencapai keadaan ini dapat dimungkinkan karena kondisi lingkungan sekitar (keluarga maupun komunitas) tidak memiliki peran yang signifikan yang membuat lansia memiliki keterikatan baik secara emosional.

Kebahagiaan personal akan tercapai apabila terjadi kesesuaian antara cita-cita seseorang dengan kenyataan yang dihadapi sekarang, baik menyangkut prestasi atau berbagai dimensi lain. Kebahagiaan merupakan 
tujuan utama dalam kehidupan seseorang, menunjukkan kenikmatan atau kepuasan terhadap hidup. Kebahagiaan personal dalam Oxford Happiness Questionairre (OHQ) (Hills, 2002) dikaji dalam 8 faktor yakni : (1) Merasa kehidupan merupakan suatu anugerah (Life is Rewading); (2) Mental selalu berpikiran positif (Mentally Alert); (3) Merasa bahagia dengan diri (Pleased with Self); (4) Menemukan keindahan diberbagai kondisi dan situasi (Find Beauty in thing); (5) Merasa puas dengan kehidupan (Satisfied with Life); (6) Dapat membagi waktu (Can Organise Time); (7) Terlihat menarik (Look Attractive); (8) Memiliki ingataningatan bahagia (Happy Memories).

Dukungan sosial yang positif akan membantu kesejahteraan psikologis individu dan menyebabkan penyesuaian diri lebih baik secara keseluruhan. Cohen dan Wills (dalam Rook, 1990) mengidentifikasi empat aspek dukungan sosial, yaitu: dukungan emosional, dukungan instrumental, dukungan informasi, dan dukungan penilaian. Dukungan sosial sangat penting dalam kehidupan individu, terlebih dalam kehidupan para lansia. Individu sebagai makhluk sosial selalu berhubungan satu sama lain, menjalin relasi, berinteraksi dan saling membutuhkan. Saat usia lansia tempat tinggal akan seseorang akan lebih bervariasi, beberapa lansia lebih senang tinggal di rumah sendiri, bersama anak ataupun saudara, dan beberapa yang lain karena satu dan lain hal tinggal di panti jompo. Keadaan lingkungan tinggal dapat mempengaruhi keadaan psikologis individu. Penelitian ini memiliki tujuan untuk mengetahui perbedaan kebahagiaan personal dan dukungan sosial pada lansia di komunitas keluarga dan panti jompo, serta hubungan antara dukungan sosial dan kebahagiaan personal pada lansia.

\section{METODE}

\section{Sampel}

Subjek penelitian adalah lansia dengan kisaran usia 55 tahun keatas yang tinggal di komunitas keluarga dan di panti jompo. Dengan jumlah subjek penelitian50 lansia yang tinggal di komunitas keluarga dan 50 lansia yang tinggal di panti jompo. Lansia di komunitas keluarga adalah lansia yang tinggal di rumah dan panti jompo yang digunakan sebagai tempat penelitian adalah Panti Werdha Pangesti yang terletak di daerah Lawang, Kab. Malang. Proses pengambilan subjek penelitian dengan quota random sampling

\begin{tabular}{lcc}
\hline \multicolumn{1}{c}{ Data Demografi } & Jumlah & \% \\
\hline Jenis Kelamin & & \\
Laki-Laki & 36 & 36 \\
Perempuan & 64 & 64 \\
Agama & & \\
Islam & 62 & 62 \\
Budha & 4 & 4 \\
Katolik & 21 & 21 \\
Kristen & 13 & 13 \\
Marital Status & & \\
Menikah & 54 & 54 \\
Duda/Janda & 33 & 33 \\
Tidak Menikah & 13 & 13 \\
Tinggal & & \\
Rumah Sendiri & 50 & 50 \\
Panti Jompo & 50 & 50 \\
Usia & & \\
55 - 67 tahun & 50 & 50 \\
68 - 80 tahun & 32 & 32 \\
$>81$ tahun & 18 & 18 \\
\hline
\end{tabular}




\section{Pengukuran}

Dalam proses pengumpulan data, pengukuran dilakukan melalui skala atau kuesioner. Skala yang dipakai antara lain : (a) Skala Tingkat Kebahagiaan Personal (Personal Happiness), adaptasi dari skala baku yaitu OHQ (The Oxford Happiness Questionairre) berjumlah 29 aitem, dengan 5 pilihan jawaban; dan (b) Skala Dukungan Sosial yang dikembangkan oleh peneliti dengan jumlah aitem sebelum pengujian adalah 40 aitem, dengan 4 pilihan jawaban.

Skala yang digunakan untuk mengukur kebahagiaan personal adalah skala baku yakni The Oxford Happiness Questionairre (OHQ). Alat ukur ini dikembangkan di Inggris sekitar tahun 1998 dengan set asli berbahasa inggris. Hasil uji validitas internal skala baku ini antara 0,26 - 0.69 dengan $p<0,001$, sehingga secara konten isi tiap-tiap aitem telah menggambarkan kekuatan dalam mengukur kebahagiaan personal seseorang (Hills, 2002). Sedangkan uji reliabilitas pada skala OHQ dengan koefisien alpha sebesar 0,93 (Hills, 2002). Sedangkan hasil uji reliabilitas yang dilakukan peneliti pada 40 partisipan diperoleh koefisien alpha cronbach sebesar 0.896 .

Sedangkan Skala dukungan sosial keluarga memiliki nilai validitas antara antara $0.320-0.671$, serta relibialitas dengan koefisien dengan alpha cronbach sebesar 0.925. Hasil uji validitas skala dukungan sosial degan total 40 aitem yang dibuat setelah dilakukan uji validisi diperoleh full-set skala untuk turun lapangan berjumlah 30 aitem.

\section{ANALISIS DATA}

Data yang terbentuk adalah data komparasi dan data korelatif. Data komparatif digunakan untuk mengetahui perbedaan Dukungan Sosial (social support) dan Kebahagiaan Personal (Personal Happiness) pada Lansia di Komunitas Keluarga dan Panti Jompo. Uji komparatif dilakukan dengan T-test dan uji korelatif dilakukan dengan korelasi spearmanbrown.

\section{HASIL}

\section{Analisa Komparatif}

Hasil uji analisis dengan teknik komparatif untuk menguji perbedaan kebahagiaan personal lansia di komunitas keluarga dan panti jompo, serta perbedaan dukungan sosial di komunitas keluarga dan panti jompo diperoleh hasil sbb:

\begin{tabular}{lllcc}
\hline & & F & Sig & Keterangan \\
\hline $\begin{array}{l}\text { Kebahag } \\
\text { iaan } \\
\text { Personal }\end{array}$ & $\begin{array}{l}\text { Komunitas } \\
\text { Keluarga } \\
\text { Panti Jompo }\end{array}$ & 0.373 & 0.543 & $\begin{array}{c}\text { Tidak } \\
\text { Signifikan }\end{array}$ \\
\hline $\begin{array}{l}\text { Dukung } \\
\text { an Sosial }\end{array}$ & $\begin{array}{l}\text { Komunitas } \\
\text { Keluarga } \\
\text { Panti Jompo }\end{array}$ & 0.695 & 0.406 & $\begin{array}{c}\text { Tidak } \\
\text { Signifikan }\end{array}$ \\
\hline
\end{tabular}

Dari uji hipotesa perbedaan kebahagiaan personal antara lansia di komunitas keluarga dan panti jompo diketahui tidak ada perbedaan yang signifikan diantara kedua tempat tinggal lansia tersebut $(\mathrm{F}=0.373$; $p>0.543$ ). Sedangkan hasil uji hipotesa perbedaan dukungan sosial keluarga antara lansia di komunitas keluarga dan panti jompo diketahui tidak memiliki perbedaan yang signifikan $(\mathrm{F}=0.695 ; \quad p$ >0.406). Dari hasil uji hipotesa dapat disimpulkan bahwa dukungan sosial memiliki kesamaan diantara lansia di komunitas keluarga dan panti jompo. 


\section{Analisis Korelasi}

Hasil uji hipotesis mengenai hubungan dukungan sosial dan kebahagiaan personal pada lansia diperoleh hasil sbb:

\begin{tabular}{cccc}
\hline & r & Sig & Keterangan \\
\hline $\begin{array}{c}\text { Dukungan } \\
\begin{array}{c}\text { Sosial*Kebahagiaan } \\
\text { Personal }\end{array}\end{array}$ & 0.686 & 0.000 & $\begin{array}{c}\text { Ada } \\
\text { Hubungan }\end{array}$ \\
\hline
\end{tabular}

Dari hasil uji coba korelatif diperoleh hasil ada hubungan yang signifikan antara dukungan sosial dan kebahagiaan personal $\quad(\mathrm{r}=0.686$; $p=0.000)$. Korelasi bernilai positif menunjukkan bahwa semakin tinggi dukungan sosial seseorang maka akan semakin tinggi pula tingkat kebahagiaan personal, begitupun sebaliknya.

\section{Pembahasan dan Diskusi}

Dari hasil tersebut dapat disimpulkan bahwa kebahagiaan personal seseorang khususnya lansia tidak dapat diukur dari ukuran tempat tinggal mereka, asumsi mengenai lansia di panti jompo kurang memiliki kebahagiaan daripada lansia yang tinggal di komunitas keluarga sepenuhnya belum terbukti. Bahagia dan tidak bahagia seseorang bukan dilihat dari dimana seseorang tinggal, karena kebahagiaan merupakan hal yang personal dan subjektif.

Bahwa tidak dapat menjadi acuan apakah seorang lansia memiliki dukungan sosial yang tinggi atau rendah ketika mereka tinggal di komunitas keluarga dan panti jompo. Lansia yang tinggal di panti jompo tidak menutup kemungkinan juga memiliki dukungan sosial dari lingkungan sosialnya, walaupun lingkup sosial mereka kemungkinan jauh lebih sempit dibanding dengan lansia yang tinggal di komunitas keluarga. Namun perasaan tentang bagaimana lingkungan memperlakukan mereka tidak memiliki perbedaan yang signifikan antara lansia di komunitas keluarga dan di panti jompo. Rook (1990) menunjukkan bahwa Dukungan sosial menjadi sumber yang penting dalam peningkatan psychological well-being pada lansia. Penelitian-penelitian tersebut menjadi dasar bahwa kebahagiaan pada lansia juga didasari oleh dukungan sosial terutama dukungan sosial keluarga. Oleh karena itu dukungan sosial terutama dari keluarga dan orang-orang terdekat lain dapat meningkatkan kebahagiaan serta harapan hidup bagi lansia.

Keadaan sosial memiliki hubungan dengan kebahagiaan dan well-being lansia. Dalam penelitian yang dilakukan oleh Purnomo (2009) disimpulkan bahwa dukungan sosial memiliki pengaruh terhadap kepuasan hidup seseorang, dalam hal ini puas atau tidaknya hidup seseorang bisa dilihat dari apakah seseorang tersebut bahagia atau tidak.

Saran untuk penelitian selanjutnya guna menunjang perbedaan dukungan sosial dan kebahagiaan personal pada lansia di komunitas keluarga dan panti jompo mungkin dengan menambah jumlah sampel penelitian dan tidak hanya memakai satu panti jompo namun beberapa panti jompo dengan variasi dari segi fasilitas dan layanan. Dari beberapa penelitian ini maupun yang telah ada terkait lansia diharapkan dapat membantu pengembangkan program-program terkait peningkatan kualitas hidup dan keadaan psikologis lansia. 
Selain itu beberapa penelitian lain terkait kebahagiaan pada lansia dapat dilakukan dengan menghubungkan dengan faktor-faktor lain yang mempengaruhi, misal: kesehatan, aktivitas, tipe kepribadian, spiritualitas, dll. Sehingga dapat lebih meningkatkan pemahaman terhadap permasalahanpermasalahan terkait gerontolis.

\section{DAFTAR PUSTAKA}

Azwar, Syaifuddin. 2003. Penyusunan

Skala Sikap. Yogyakarta: Pustaka Belajar

Hills, Petter \& Michael Argyle. 2002. The Oxford Happiness Questionnaire: A Compact Scale for The Measurement of Psychological Well-Being. Personality and Individual Difference. 33(2002): 1073-1082

Kashdan, Todd B. 2004. The assessment of subjective well-being (issues raised by the Oxford Happiness Questionnaire). Personality and Individual Difference. 36 (2004): 1225.-1232

Komisi Lanjut Usia. 2010. Profil Penduduk Lanjut Usia 2009. Jakarta Collins, Amy L., Natalia S., Ellen Winner. 2008. Flow Happiness in Later Life:An Investigation into the Role Daily and Weekly Flow Experiences. Research Paper. Boston: Springer Science and Business Media.

Monks, F. J., Knoers, A.M.P., \& Haditono, S.R. 2002. Psikologi Perkembangan Pengantar dalam Berbagai Bagiannya. Yogyakarta: UGM Press

Papalia, Olds, Feldman. 2009. Human

Development: Perkembangan
Manusia Buku 2. Edisi 10. Jakarta :

Salemba Humanika

Purnomo, Akhmad. 2009. Kepuasan

Hidup dan Dukungan Sosial

Lanjut Usia. Yogyakarta: B2P3KS Press

Ryff, Carol D. 1989. Happiness is Everything, or is it? Exploration on the Meaning of Psychological WellBeing. Journal of Personality and Social Psychology. Vol. 57, No. 6, 1069-1081

Sopiyudin, M. Dahlan. 2011. Statistik Untuk Kedokteran dan Kesehatan. Jakarta: Salemba Medika

Tamher, S \& Noorkasiani. 2009. Kesehatan Usia Lanjut dengan

Pendekatan Asuhan Keperawatan. Jakarta: Salemba Medika.

Tayag, Arelene G. Assessing Social Support in Children: Development $\mathcal{E}$ Initial Validation of The Social Support Questionnaire for Children. Dissertation. 2011. Lousiana University. 